\title{
Toxicity of paper mill pelletized waste using germination and biomass production as bioindicators
}

\author{
Pablo Undurraga ${ }^{1,5}$, Juan Hirzel ${ }^{1}$, José Celis ${ }^{2}$, Carla Pérez³ , and Marco A. \\ Sandoval ${ }^{4}$ \\ ${ }^{1}$ Instituto de Investigaciones Agropecuarias, INIA Quilamapu. Av. Vicente Méndez 515, Chillán, Chile. \\ ${ }^{2}$ Universidad de Concepción, Facultad de Ciencias Veterinarias. Av. Vicente Méndez 595, Chillán, Chile. \\ ${ }^{3}$ Universidad de Concepción, Unidad de Desarrollo Tecnológico (UDT). Cordillera 2634, Coronel, Chile. \\ ${ }^{4}$ Universidad de Concepción, Facultad de Agronomía. Av. Vicente Méndez 595, Chillán, Chile. \\ ${ }^{5}$ Universidad de Concepción, Programa de Graduados Doctorado en Ciencias de la Agronomía. Av. Vicente \\ Méndez 595, Chillán, Chile.
}

\begin{abstract}
P. Undurraga, J. Hirzel, J. Celis, C. Pérez, and M.A. Sandoval. 2018. Toxicity of paper mill pelletized waste using germination and biomass production as bioindicators. Cien. Inv. Agr. 45(2): 147-157. The use of wood residues to produce energy and steam in the pulp and paper industry generates ash waste and sewage sludge that contain nutrients for plants as a potential fertilizer. The objective of this study was to evaluate the possible toxic effects of pelletized waste from the pulp and paper industry using bioindicators. Two controlled experiments were conducted with radish seeds and perennial ryegrass seeds: an experiment to determine the germination index and root growth in soil extracts incubated with pelletized waste, and a pot experiment with ryegrass seeds sown in an amended Alfisol with pelletized wastes in which aerial and root biomass production was determined. The results indicate that the Alfisol amended with pelletized waste did not exhibit any acute or sub-acute toxic effects in radish germination. None of the evaluated pellets showed evidence of deterioration in root elongation, including at a $40 \mathrm{Mg} \mathrm{ha}^{-1}$ dose. The highest root growth was with pellet 2, with ash and sludge at the $40 \mathrm{Mg} \mathrm{ha}^{-1}$ dose, which was higher than that in the control treatment $(p<0.05)$. Seed germination was between $93.9 \%$ and $100 \%$. The highest ryegrass aerial biomass occurred with pellets 1 and $2(\mathrm{p}<0.05)$. Pelletized waste from the paper industry exhibited neither mild nor acute effects of toxicity in both radish seed germination and aerial and root biomass production of ryegrass sown in degraded soil.
\end{abstract}

Key words: Pelletized ash/sludge, pelletized waste, pulp and paper mill waste, radish, ryegrass, toxicity bioassay.

\section{Introduction}

Waste management in the pulp and paper industry has been mainly limited to the collecting and dis-

Received Sep 16, 2017. Accepted Jun 04, 2018. Corresponding author: masandov@udec.cl posing of waste in garbage dumps and landfills, with little awareness of assessment alternatives. The lack of waste assessment is mainly attributable to legal and procedural barriers, which discourage the implementation of projects that attempt to reuse or valorize organic waste (Arellano and Ginocchio, 2013). 
The three main agricultural and forestry products exported by Chile in 2014 were cellulose, grapes, and wine with protected designation of origin; cellulose represents the highest export percentage being $16 \%$ of the total. Cellulose production capacity is based on 16.6 million hectares of forest cover, of which 2.7 million are radiata pine (Pinus radiata D. Don) and eucalyptus (Eucalyptus globulus Labill.) plantations. This production allows Chile to produce almost 6 million tons of cellulose annually, and two thirds of the total capacity is concentrated in the Biobío Region (ODEPA, 2014).

A waste assessment alternative for the pulp and paper industry is using waste products to improve degraded and eroded soils, a problem affecting most of the agricultural and forestry soils worldwide. In Chile, $64 \%$ of soils exhibit some type of erosion, and the Biobío Region has 32\% of its area with some degree of erosion (CIREN, 2010). Eroded soils could be used as reservoirs to recycle waste; however, this recycling has been curtailed by the social factors, especially in the case of biosolids, because of the concerns of communities about the possible effects of environmental pollution (Arellano and Ginocchio, 2013).

The paper industry annually generates approximately $4960 \mathrm{Mg}$ of non-hazardous industrial waste, including sludge, ash, and residual water, in the Biobío Region at a rate of 15 to $30 \mathrm{~kg}$ for each ton of paper produced. This industrial waste is mainly ash from biomass combustion and sludge from the effluent treatment systems. Therefore, waste should be investigated and tested to ensure that it does not contain any dangerous compounds, such as resin acids or heavy metal concentrations, which surpass the established norms and can limit its soil application (Rios et al., 2012), as well as rule out toxic effects for grasslands, crops, and forest plantations.

Waste from the pulp and paper industry improves soil fertility; increases organic matter (OM) contents, including nutrient content such as $\mathrm{N}, \mathrm{P}$, and $\mathrm{K}$; and can increase the $\mathrm{pH}$ of acidified soils, which could be an alternative to using commercial lime (Faubert et al., 2016). Waste products can also improve physicochemical aspects, such as the structure and stability of aggregates, and enhance cation exchange capacity.

The first important evaluation stage is to determine the toxicity of waste that will be applied as soil amendments (Arellano and Ginocchio, 2013). Toxicity bioassays evaluate the success or aptitude of a plantlet established in a given environment (Sobrero and Ronco, 2004) because phytotoxicity results from a combination of factors that interfere with plant germination and growth, such as exposure to heavy metals, ammonia, and salts (Hoekstra et al., 2002; Teaca and Bodirlau, 2008). The excess of heavy metals (e.g., Cd, Cr, $\mathrm{Cu}, \mathrm{Ni}, \mathrm{Pb}$, and $\mathrm{Zn}$ ) is contaminative and toxic for crops and can inhibit seed germination and root elongation when their concentration surpasses levels tolerated by plants (Chapman et al., 2010). Toxicity bioassays can be conducted with plants, and two species commonly used are wheat (Triticum aestivum L.) and lettuce (Lactuca sativa L.), as well as the crustacean known as the water flea (Daphnia magna), and the bioassays are standardized as analytical methods (ISO11269-2, 2012, ISO17126, 2005).

Celis et al. (2007) evaluated toxicity by applying extracts of an Alfisol soil mixed with salmon farming sludge and municipal sludge; they used the germination and development capacity of lettuce seeds as indicators with doses equivalent to $100 \mathrm{Mg} \mathrm{ha}^{-1}$ dry sludge. Furthermore, salmon farming, fish farming, and urban sludge biosolids were applied to Entisol (Celis et al., 2006) to determine the germination index (GI), radicle growth, and hypocotyl development of lettuce with calculated doses of $150 \mathrm{Mg} \mathrm{ha}^{-1}$. Other species, such as watercress (Lepidium sativum L.), barley (Hordeum vulgare L.), and oat (Avena sterilis L.) have also been used to evaluate sludge extracts from wastewater treatment (Rios et al., 2012; Sobrero and Ronco, 2004). Papermill biosolids are a 
valuable waste with a low metal content that can increase total soil $\mathrm{C}$ and $\mathrm{N}$. They provide a good source of $\mathrm{N}$ through mineralization, and makes $\mathrm{P}$ and $\mathrm{S}$ readily available to crops (Gagnon and Ziadi, 2012). Assays have also been conducted with ryegrass in pots to evaluate the effects of residues in soil under controlled conditions (San Martin et al., 2016; Sandoval et al., 2013). Additionally, pulp and paper mill waste can be used to amend degraded soils and to create their sustainable use. In addition, pelletizing facilitates transport and requires only a single application to evenly distribute sludge and ashes on soil that needs to be amended (Undurraga et al., 2017). The hypothesis is that the application of pelletized amendments composed of ash and sludge from the paper industry has a toxic effect on crops. The objective of this study was to evaluate the phytotoxicity of waste from the paper industry and its potential as an amendment in a degraded Alfisol soil by applying increasing doses of pellets composed of ash and sludge and using radish and ryegrass as indicator plants.

\section{Materials and Methods}

\section{Pellets and soil used in phytotoxicity experiments}

The Papeles Biobío Company, Biobío Region, Chile generates waste used to manufacture pellets. Pellets were produced by compressing fly ash from the multicyclone and precipitator and biomass combustion residues from energy generation in a 50:50 w/w ratio. Pellets mostly consisted of ash (56\% to $70 \%$ ), to which $0 \%$ to $20 \%$ sewage sludge was added (Table 1) and $24 \%$ to $30 \%$ gypsum was used for bonding and cementing. Three types of pellets were manufactured with different proportions of sludge and ash (Table 1). Pellets were experimentally produced by the Technological Development Unit (Unidad de Desarrollo Tecnológico, UDT) of the Universidad de Concepción. To conduct the experiments, the pellets were crushed to increase soil contact.
Table 1. Percentage composition of pellets experimentally manufactured by compression.

\begin{tabular}{|c|c|c|c|}
\hline & Fly ash & Sludge & Gypsum \\
\hline & -—- & $--\%$ & --— \\
\hline Pellet 1 & 70 & 0 & 30 \\
\hline Pellet 2 & 63 & 10 & 27 \\
\hline Pellet 3 & 56 & 20 & 24 \\
\hline
\end{tabular}

The soil used for the toxicity experiments was a degraded Alfisol obtained at a $20 \mathrm{~cm}$ depth from the Huape sector (36 $37^{\prime} 19^{\prime \prime}$ S, $\left.72^{\circ} 19^{\prime} 42^{\prime \prime} \mathrm{W}\right)$, Biobío Region, Chile. The soil belongs to the Cauquenes series, is classified as Ultic Palexeralfs (Stolpe et al., 2008) and has an apparent density of $1.2 \mathrm{~g} \mathrm{~cm}^{-3}$ under cereal and naturalized grassland cultivation with degradation caused by water erosion. Natural vegetation is mainly hawthorn (Vachellia caven (Molina) Seigler \& Ebinger) and litre (Lithraea caustica (Molina) Hook. \& Arn.). Soil was dried at room temperature and sieved with a $2 \mathrm{~mm}$ sieve (Sandoval et al., 2012). It exhibited the typical chemical characteristics of eroded soil with low fertility levels; $2.02 \% \mathrm{OM}$; pH 6.16 in water; mineral $\mathrm{N}$ and Olsen $\mathrm{P}$ values of 4.3 and $2.0 \mathrm{mg} \mathrm{kg}^{-1}$, respectively; and medium to low exchange base values of $0.41,5.08$, and $1.42 \mathrm{cmol}_{(+)} \mathrm{kg}^{-1}$ for $\mathrm{K}, \mathrm{Ca}$, and $\mathrm{Mg}$, respectively. Micronutrient levels of $\mathrm{B}, \mathrm{Zn}$, and $\mathrm{Cu}$ were 0.1 , 0.8 , and $1.1 \mathrm{mg} \mathrm{kg}^{-1}$, respectively; these values were determined by methods described by Sadzawka et al. (2006) as follows: pH was measured in a 1:2.5 (w/v) soil/water mixture, while available $\mathrm{P}$ (P Olsen) was extracted with sodium bicarbonate (0.5 M, pH 8.5) and determined colorimetrically by the molybdate-ascorbic acid method. Available macro- and microelements were determined by atomic absorption spectrophotometry (Shimadzu GBC Sens AA). Ca, Mg, K, and $\mathrm{Na}$ were quantified after extraction with $1 \mathrm{M}$ ammonium acetate, with $\mathrm{pH}$ 7.0. On the other hand, $\mathrm{Fe}, \mathrm{Mn}, \mathrm{Cu}$ and $\mathrm{Zn}$ were quantified after extraction with diethylenetriaminepentaacetic acid (DTPA), calcium chloride, and triethanolamine (TEA), buffered at $\mathrm{pH}$ 7.3. Al was quantified after extraction with 1 
$\mathrm{M} \mathrm{KCl}$ (1:10 soil:solution ratio). Available $\mathrm{SO}_{4}-$ $\mathrm{S}$ was extracted with $0.01 \mathrm{M} \mathrm{Ca}\left(\mathrm{H}_{2} \mathrm{PO}_{4}\right)_{2}$ and determined by turbidimetry. Available $\mathrm{B}$ was determined by extraction with $0.01 \mathrm{M} \mathrm{CaCl}_{2}$ and colorimetry with azomethine.

\section{Phytotoxicity experiment with radish seeds}

Three types of disaggregated pellets were added to $110 \mathrm{~g}$ sieved and air-dried Alfisol soil to generate homogeneous mixtures of three pellet:soil doses equivalent to 10, 20, and $40 \mathrm{Mg} \mathrm{ha}^{-1}$. The mixtures were placed in polyethylene bags and incubated for $15 \mathrm{~d}$ in a growth chamber at a constant temperature of $20{ }^{\circ} \mathrm{C}$-which is necessary to complete the soil amendment treatment and stabilization process (Rios et al., 2012). The moisture content was maintained at field capacity. A control treatment with soil only was included, and the experiment occurred in triplicate. After incubation, $5 \mathrm{~g}$ of the mixture of each treatment (soil/pellets) was weighed in a plastic bottle, and $50 \mathrm{~mL}$ of distilled water was added in a ratio of 1:10. The mixture was shaken at $180 \mathrm{rpm}$ for $20 \mathrm{~min}$, and $4 \mathrm{~mL}$ of the extract was taken and placed in a Petri capsules with Whatman $\mathrm{N}^{\circ} 3$ filter paper disc, according to (Celis et al., 2008). Twenty radish seeds were carefully placed using tongs with enough space between them to allow radicle germination and elongation. Capsules were placed in a germination chamber where they were maintained for $120 \mathrm{~h}$ at $20 \pm 2{ }^{\circ} \mathrm{C}$ in darkness and constant humidity of $100 \%$ inside the petri capsule. Capsules with distilled water were included as a negative control to ensure the radish seed germination potential; a positive control to ensure germination inhibition consisted of a $0.01 \mathrm{M} \mathrm{Zn(II)} \mathrm{salt} \mathrm{concentration}$ as a toxic reference.

The applied experimental design was a completely randomized factorial arrangement with three replicates. The factors were dose and pellet type.
Phytotoxicity was determined by GI as suggested by Tiquia and Tam (1998), allowing the evaluation of the low or minor toxicity that affects root growth, as well as the high or major toxicity (Nafez et al., 2015; Unuofin et al., 2016), to determine the effect on radish seed germination, as expressed in equation 1 :

$$
G I=\frac{G_{c} x L_{c}}{G x L} \times 100
$$

where $G I$ is the germination index (\%), $G$ is the mean of germinated seeds in the sample, $G_{\mathrm{c}}$ is the mean of germinated seeds in the negative control, $L$ is the mean of radicle length in the sample (mm), and $L_{c}$ is the mean of radicle length in the negative control ( $\mathrm{mm})$. The value of GI can vary from 0 to more than $100 \%$.

After $120 \mathrm{~h}$, plantlets in the Petri capsules were counted and meticulously observed for any phytotoxicity indicator, such as necrotic root apices or poor development of absorbent hairs. The number of normally germinated seeds was recorded; the germination criterion was the visible radicle being at least $5 \mathrm{~mm}$ in length. The radicle length of all the germinated seeds was also carefully measured a Vernier caliper.

\section{Potted ryegrass biomass production}

The experiment was conducted in pots under controlled conditions in the greenhouse of the Faculty of Agronomy of the Universidad de Concepción, Chillán. Each treatment used $1 \mathrm{~kg}$ of soil sieved with a $2 \mathrm{~mm}$ sieve and dried at room temperature (Sandoval et al., 2013). The dose of disaggregated pellets was added to the soil of each pot of $0.5 \mathrm{~L}$ with a diameter of 8 $\mathrm{cm}$ and $10 \mathrm{~cm}$ of high, and the pellet and soil mixture was homogenized in a polyethylene bag. The treatment factors considered three types of pellets at four doses of $0,10,20$, and $40 \mathrm{Mg}$ ha $^{-1}$; ryegrass 'Nui' was sown at a dose of $1.5 \mathrm{~g}$ per pot with seeds previously disinfected with 
thiram $0.5 \%$ fungicide. The experiment lasted three months and soil moisture was maintained at $80 \%$ field capacity (FC).

The experimental design was completely randomized with a factorial arrangement with four replicates. It included twelve treatments with four doses and three types of pellets, including a control treatment with only soil.

The aerial biomass evaluations were carried out with three cuttings when the ryegrass reached a height of $10 \mathrm{~cm}$, leaving $2 \mathrm{~cm}$ of residue; this occurred 21 to $26 \mathrm{~d}$ between cuttings. Dry matter was measured at each cutting and the three cuttings were totaled. After the last cutting, plants were unpotted to quantify DM in the roots by carefully washing them with plenty of water. The DM of each ryegrass cutting and of the roots was determined by drying at $60{ }^{\circ} \mathrm{C}$ in a forced-air oven until constant weight (Sandoval et al., 2013).

\section{Statistical analysis}

The statistical analysis of the data from the toxicity experiment with radish seeds and ryegrass biomass was performed with ANOVA, while the effect of means was analyzed by Tukey's test with a confidence level of $95 \%(\alpha=0.05)$. The data were analyzed with SAS software (SAS Institute, Cary, North Carolina, USA).

\section{Results and Discussion}

Phytotoxicity of evaluated pellets with radish seeds

In toxicity tests, inhibiting radicle or hypocotyl elongation has a sublethal effect, whereas inhibiting germination has a lethal effect. However, it must be corroborated that the seeds do not germinate because of embryo death; it must be ruled out that it was not simply a delay in the germination process, and seed viability was maintained (Gvozdenac et al., 2016; Rios et al., 2012).
Radish seed germination experiments in extracts of Alfisol incubated with different doses and pellets did not exhibit any toxic effects, including with the high doses up to $40 \mathrm{Mg} \mathrm{ha}^{-1}$. These revealed no deterioration in radicle germination or elongation in any of the evaluated pellets. On the other hand, positive effects were detected on the evaluated parameters according to ANOVA with the Dose $\times$ Pellet type interaction. The highest radicle elongation in some treatments compared to the control (Table 2) is possibly attributable to positive stimulation (Teaca and Bodirlau, 2008). The highest radicle growth was obtained for pellet 2 at the $40 \mathrm{Mg} \mathrm{ha}^{-1}$ dose with a value of $14.03 \mathrm{~mm}$, which was slightly higher than the $11.71 \mathrm{~mm}$ value in the control treatment but was not significantly different. Lower radicle growth values were exhibited in treatments with pellet 1 at $10 \mathrm{Mg}$ $\mathrm{ha}^{-1}$, pellet 2 at $20 \mathrm{Mg} \mathrm{ha}^{-1}$, and pellet 3 at $40 \mathrm{Mg}$ $\mathrm{ha}^{-1}$, whose values were 11.52, 11.27 , and $11.29 \mathrm{~mm}$, respectively (Table 2). However, subacute toxicity cannot be considered because these values do not differ from the control ( $p>0.05)$. Some plant species or populations are sensitive to abiotic stress or can be tolerant and show small inhibitions in germination or development in primary stages (Gvozdenac et al., 2016; Mekki et al., 2017). However, synergetic effects of doses and pellet types in our study generated positive effects in radicle elongation, GI, and radish seed germination (Table 2), similar to those found by Undurraga et al. (2017) with pellet 2 that presented the best response in incubation experiments of a degraded Alfisol, estimating that a proportion of sludge of $10 \%$ is more adequate (Table 1 ).

Heavy metals or volatile substances can inhibit plant germination and growth and influence germination time (Nafez et al., 2015). Given the applied doses, the concentration of metals or other substances did not generate any level of toxicity in pellets consisting of solid waste from the pulp and paper industry. The GI values were between $125.9 \%$ and $167.9 \%$, and the germinated seeds were between $93.9 \%$ and $100 \%$ (Table 2). A GI greater than $80 \%$ indicates phytotoxicity-free material, and a value less than $50 \%$ indicates a high phytotoxicity level (Tiquia and Tam, 1998). 
Table 2. Germination index (GI), germination (G), and radicle length of radish seeds germinated in soil extracts incubated with soil/pellet mixture in an Alfisol amended with different doses and pellet types.

\begin{tabular}{lcccc}
\hline Treatments & Dose & GI & G & Radicle length \\
\hline Control & & \multicolumn{2}{c}{$\%$} & $\mathrm{~mm}$ \\
Pellet 1 & 0 & $140.2 \mathrm{abc}$ & $100.0 \mathrm{a}$ & $11.71 \mathrm{ab}$ \\
Pellet 1 & 10 & $134.0 \mathrm{abc}$ & $100.0 \mathrm{a}$ & $11.52 \mathrm{~b}$ \\
Pellet 1 & 20 & $140.4 \mathrm{abc}$ & $100.0 \mathrm{a}$ & $11.73 \mathrm{ab}$ \\
Pellet 2 & 40 & $145.8 \mathrm{abc}$ & $96.7 \mathrm{ab}$ & $12.58 \mathrm{ab}$ \\
Pellet 2 & 10 & $163.8 \mathrm{a}$ & $100.0 \mathrm{a}$ & $13.69 \mathrm{ab}$ \\
Pellet 2 & 20 & $125.9 \mathrm{c}$ & $93.3 \mathrm{ab}$ & $11.27 \mathrm{~b}$ \\
Pellet 3 & 40 & $167.9 \mathrm{a}$ & $100.0 \mathrm{a}$ & $14.03 \mathrm{a}$ \\
Pellet 3 & 10 & $159.5 \mathrm{ab}$ & $100.0 \mathrm{a}$ & $13.32 \mathrm{ab}$ \\
Pellet 3 & 20 & $150.8 \mathrm{abc}$ & $100.0 \mathrm{a}$ & $12.59 \mathrm{ab}$ \\
SE & 40 & $130.5 \mathrm{bc}$ & $96.7 \mathrm{ab}$ & $11.29 \mathrm{~b}$ \\
Conc & & 6.34 & 2.16 & 0.49
\end{tabular}

Control: Soil without amendment; SE: standard error; LSD = last significant difference. Different letters in columns indicate differences according to Tukey's test $(\mathrm{p}<0.05)$.

Seed GI is a direct indicator of residue or compost toxicity (Phoungthong et al., 2016) because it directly establishes if the residues can inhibit plant growth when used as soil amendment or as a direct means of growth. A GI greater than $80 \%$, observed for all the treatments in the present study, indicated that pellets mixed with a degraded Alfisol would have phytotoxin or heavy metal levels that do not affect plant growth (Unuofin et al., 2016); instead, evaluated indices increased as indicated by the radish seed germination tests. Agricultural application of pellets of ash and sludge may be limited by their phytotoxic effect during seedling establishment, which was assessed using the Germination Index (GI). Nevertheless, a GI that takes into account relative seed germination and relative root elongation compared to that of a control condition has been extensively used to evaluate compost toxicity and was a good method for the evaluation of pellets for use as a soil amendment (Kataki et al., 2017).

Aerial and root biomass of ryegrass amended with pellets

Fast-growing ryegrass plants were used as bioindicators of possible toxic effects of the amendment in a degraded Alfisol with ash and sludge pellets from the paper industry. The effects of dose and pellet types in the production and concentration of the aerial and root biomass of ryegrass sown in pots were evaluated (Table 3). The evaluated doses did not significantly affect biomass or DM concentration in the aerial part ( $p>0.05)$, but differences in root biomass and DM concentration were found ( $p<0.05$; Table 3$)$. On the other hand, pellet type show $46 \mathrm{~g}$ per pot (Figure 1) after three cuttings in the three months that the experiment lasted. The low amounts of biomass were due to the low fertility of the degraded Alfisol, especially low levels of N, P, and micronutrients such as B. It must also be considered that the pellets contributed little $\mathrm{N}$ and $\mathrm{P}$ and instead contributed $\mathrm{K}$, $\mathrm{Ca}$, and $\mathrm{S}$ because of the ash, sludge, and gypsum proportions (Table 1). The ryegrass aerial biomass values were similar to those obtained by Celis et al. (2008), who used only sludge. This outcome could explain the lower biomass production obtained with pellet 3 , which contained the highest proportion of sewage sludge (20\%; Table 1$)$. This outcome is in contrast with pellet 1 without sludge and pellet 2 including only $10 \%$.

The chemical parameters of pulp and paper mill waste used in pellet fabrication contained elements that could contribute to increased fertility in degraded soils; moreover, pellet $\mathrm{pH}$ was high (8.16), helping to reduce soil acidity and improve levels of nutrients, such as $\mathrm{Ca}, \mathrm{Mg}$, and $\mathrm{K}$, during applications to soil (Undurraga et al., 2017). The metals analyzed in bottom and fly ashes, with pellets fabrications, had high concentrations of $\mathrm{Al}$, $\mathrm{Si}$, and $\mathrm{Ti}$, being the elements with the greatest 
Table 3. ANOVA of the effects of dose and pellet type in ryegrass aerial and root biomass.

\begin{tabular}{lcccc}
\hline Source of Variation & Aerial biomass & DM content $(\%)$ Aerial & Root biomass & DM content (\%) Root \\
\hline Doses (D) & $0.1972^{\text {ns }}$ & $0.0745^{\text {ns }}$ & $0.0002^{* *}$ & $<0.0001^{* *}$ \\
Pellet (P) & $0.0101^{*}$ & $0.0003^{* *}$ & $0.2473^{\text {ns }}$ & $0.5759^{\text {ns }}$ \\
D $\times$ P Interaction & $0.0630^{\text {ns }}$ & $0.0173^{*}$ & $0.3522^{\text {ns }}$ & $0.0221^{* *}$ \\
\hline
\end{tabular}

ns: nonsignificant; *and ** significant at $\mathrm{p} \leq 0.05$ or $\mathrm{p} \leq 0.01$ by ANOVA, respectively.
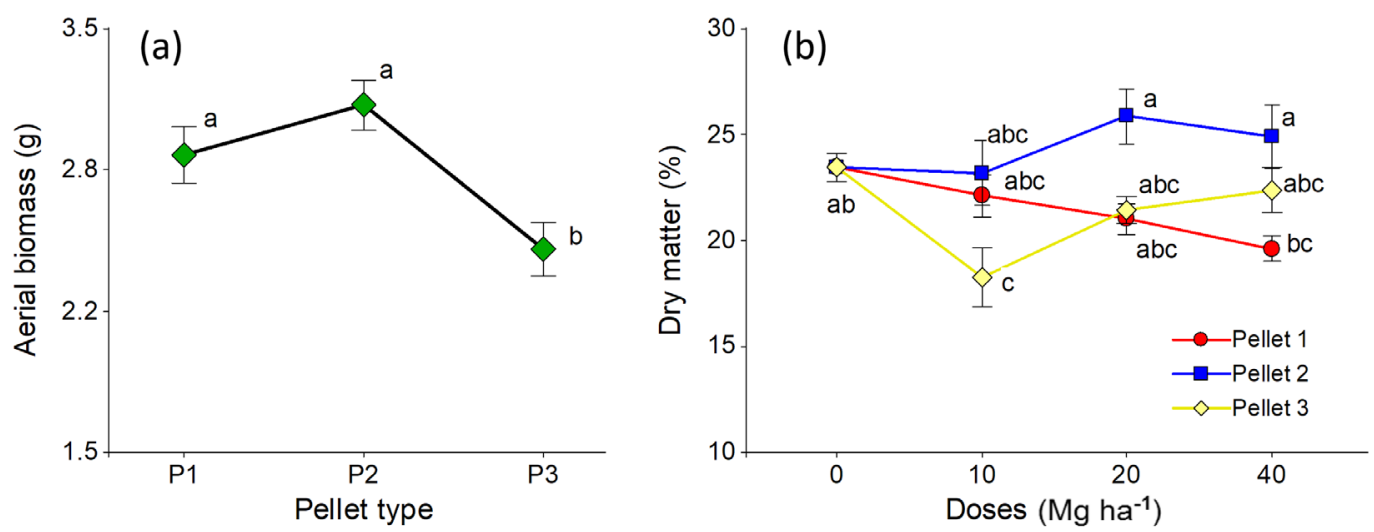

Figure 1. Ryegrass aerial biomass production with different pellet doses. (a) aerial biomass and (b) biomass dry matter concentration.
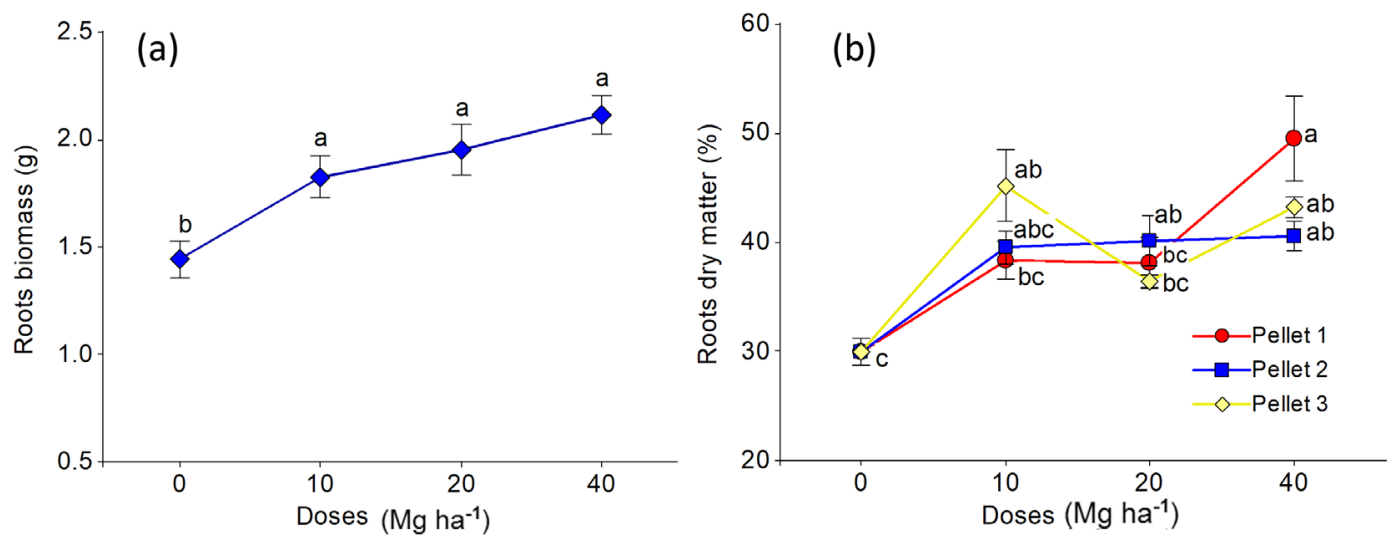

Figure 2. Ryegrass root biomass production at the end of the experiment. (a) root biomass and (b) root biomass dry matter concentration.

contribution to all the ash produced during the plant biomass combustion. The concentrations of the other metals, $\mathrm{V}, \mathrm{Cr}, \mathrm{As}, \mathrm{Ba}, \mathrm{Ni}, \mathrm{Pb}$, and $\mathrm{Co}$, were lower. In addition, $\mathrm{Cd}$ and $\mathrm{Hg}$, with values lower than 2 and $1 \mathrm{mg} \mathrm{kg}^{-1}$, respectively, were not detected in the ashes because their concentrations were below the sensitivity of the analytical method (Undurraga et al., 2017).
The dose and pellet type factors exhibited interactions on the aerial biomass DM concentration with the highest contents found for pellet 2 at the 20 and $40 \mathrm{Mg} \mathrm{ha}^{-1}$ doses with $25.9 \%$ and $24.9 \%$, respectively (Figure 1b). These values are slightly higher than those in the control treatment with soil only, indicating that the pellet amendment does not generate any toxic or detrimental effects at 
the doses tested. However, the DM content was not a good indicator of negative effects of using these pellet residues as amendments. In contrast, the root DM contents were higher than those in the aerial biomass, reaching $49.5 \%$ for pellet 1 at the $40 \mathrm{Mg} \mathrm{ha}^{-1}$ dose compared to that of the control (30\%) (Figure 2b).

Root biomass production of ryegrass exhibited differences among treatments with dose being more important than pellet type. Root biomass responded to dose and reached $2.11 \mathrm{~g}$ at the 40 $\mathrm{Mg} \mathrm{ha}^{-1}$ dose, which differed from that of the control treatment, which did not apply pellets and obtained a value of $1.44 \mathrm{~g}(\mathrm{p}<0.05)$ (Figure $2 \mathrm{~b})$. This outcome is due to the low initial fertility of the soil, owing to the degradation, showing slight increase in DM production. In other words, applying pellets with ash and sewage sludge from the paper industry is beneficial for degraded soil and is not detrimental or toxic (Adebayo et al., 2015; Sharifi et al., 2013); this finding indicates that the pellet components do not have toxic substances or heavy metals in concentrations that can affect germination or biomass production of indicator plants. This outcome has been demonstrated by several authors using ash (Huotari et al., 2015; Nayak et al., 2015; Teaca and Bodirlau, 2008) and sewage sludge (Celis et al., 2008; Faubert et al., 2016; Nafez et al., 2015). Although it is true that moderate doses do not exhibit toxic effects, they decrease the germination or biomass production of indicator plants when they are only applied in doses greater than $60 \mathrm{Mg} \mathrm{ha}^{-1}$ (Celis et al., 2008; Gerber et al., 2017). Therefore, the use of pellet amendments consisting of waste from the pulp and paper industry is a good alternative. It complements the contribution of nutrients from sewage sludge and fly ash and decreases the detrimental or toxic effects that can be generated. Pelletization also facilitates its application and uniform distribution in the field.

In conclusion, pelletized waste from the paper industry exhibits neither mild nor acute toxic effects in radish seed germination evaluated by the germination index and radicle growth. In contrast, beneficial effects were found that increased radicle development. This same behavior was demonstrated by applying the pellet with the highest proportion of ash and lower sludge content (up to $10 \%$ ), which increased aerial and root biomass production of ryegrass sown in degraded soil amended with pelletized waste. The pellet with $20 \%$ sludge at the $40 \mathrm{Mg} \mathrm{ha}^{-1}$ dose decreased aerial biomass production, whereas pellet type had no effect on root biomass.

In accordance with these results, pelletizing ash and sludge waste from the pulp and paper industry becomes an alternative for use as amendment or fertilizer in degraded soils or as a complement to forestry or agricultural production, as pellet technology facilitates the transport and application of waste. Furthermore, an alternative is generated to use environmentally sustainable waste and avoid disposal in garbage dumps.

\section{Acknowledgements}

This research was funded by the Unidad de Desarrollo Tecnológico (UDT) of the Universidad de Concepción and Project INNOVA 13IDL-25554. The UDT partially funded the research project of the Postgraduate Program in Agronomy Sciences of P. Undurraga. 


\title{
Resumen
}

\begin{abstract}
P. Undurraga, J. Hirzel, J. Celis, C. Pérez, y M.A. Sandoval. 2018. Toxicidad de residuos peletizados de la industria del papel utilizando germinación y producción de biomasa como bioindicadores. Cien.Inv.Agr. 45(2): 147-157. El uso de residuos de madera para producir energía y vapor en industrias de pulpa y papel genera residuos de cenizas y lodos de depuradora que contienen nutrientes para las plantas con potencial fertilizante. El objetivo fue evaluar posibles efectos tóxicos de residuos peletizados de industrias de pulpa y papel mediante bioindicadores. Se realizaron dos experimentos controlados con semillas de rabanitos y ballica perenne; uno determinó el índice de germinación y crecimiento de radículas en extractos de suelo incubados con residuos peletizados. El segundo fue con semillas de ballica perenne sembradas en un Alfisol enmendado con residuos peletizados, determinando producción de biomasa aérea y raíces. Los resultados indican que el Alfisol enmendado con residuos no presenta efectos tóxicos en germinación de rabanitos, incluso con $40 \mathrm{Mg} \mathrm{ha}^{-1}$ no se evidencian deterioros en germinación o elongación de radículas para ningún tipo de pellets. El mayor crecimiento de radícula se obtuvo para pellet 2 con $40 \mathrm{Mg} \mathrm{ha}^{-1}$, siendo mayor al control $(\mathrm{p}<0.05)$. La germinación de semillas estuvo entre $93.9 \%$ y $100 \%$. La mayor biomasa aérea de ballica se obtuvo con los pellets 1 y $2(\mathrm{p}<0.05)$. Los residuos peletizados de la industria del papel no presentan efectos de toxicidad leve ni aguda, tanto en la germinación de semilla de rabanito como en la producción de biomasa aérea y de raíces de ballica sembradas en un suelo degradado.
\end{abstract}

Palabras clave: Ballica, bioensayo de toxicidad, cenizas/lodos peletizados, rábano, residuos de industria de papel y celulosa, residuos peletizados.

\section{References}

Adebayo, O.S., N.A. Kabbashi, M.Z. Alam, and M.S. Mirghani. 2015. Recycling of organic wastes using locally isolated lignocellulolytic strains and sustainable technology. Journal of Material $\mathrm{Cy}$ cles and Waste Management 17:769-780.

Arellano, E., and E. Ginocchio. 2013. Desafíos de las políticas públicas de gestión de residuos orgánicos en Chile para fomentar su reutilización en sistemas degradados. In: T. d. 1. A., editor Centro de Políticas Públicas. Pontificia Universidad Catolica de Chile.

Celis, J., M. Sandoval, and R. Barra. 2008. Plant response to salmon wastes and sewage sludge used as organic fertilizer on two degraded soils under greenhouse conditions. Chilean Journal of Agricultural Research 68:274-283.

Celis, J., M. Sandoval, and M. Briones. 2007. Bioensayos de fitotoxicidad de residuos orgánicos en lechuga y ballica anual realizados en un suelo Alfisol degradado. Revista de la Ciencia del Suelo y Nutrición Vegetal 7:51-60.

Celis, J., M. Sandoval, E. Zagal, and M. Briones. 2006. Efecto de la adición de biosolidos urbanos y de salmonicultura sobre la germinación de semillas de lechuga (Lactuca sativa L.) en un suelo patagonico. Revista de la Ciencia del Suelo y Nutrición Vegetal 6:13-25.

CIREN. 2010. Determinación de erosión potencial y actual de Chile. In: I. T. F. INNOVA-Chile, editor Informe Tecnico Final INNOVA-Chile. Centro de Informacion de Recursos Naturales, MINAGRI, Chile.

Chapman, E.E.V., G. Dave, and J.D. Murimboh. 2010. Ecotoxicological risk assessment of undisturbed metal contaminated soil at two remote lighthouse sites. Ecotoxicology and Environmental Safety 73:961-969.

Faubert, P., S. Barnabe, S. Bouchard, R. Cote, and C. Villeneuve. 2016. Pulp and paper mill sludge 
management practices: What are the challenges to assess the impacts on greenhouse gas emissions? Resources Conservation and Recycling 108:107-133.

Gagnon, B., and N. Ziadi. 2012. Papermill biosolids and alkaline residuals affect crop yield and soil properties over nine years of continuous application. Canadian Journal of Soil Science 92:917-930.

Gerber, M.D., T. Lucia, L. Correa, J.E.P. Neto, and E.K. Correa. 2017. Phytotoxicity of effluents from swine slaughterhouses using lettuce and cucumber seeds as bioindicators. Science of the Total Environment 592:86-90.

Gvozdenac, S., V. Bursic, G. Vukovic, S. Duric, C. Goncalves, D. Jovicic, and S. Tanaskovic. 2016. Phytotoxic effects of irrigation water depending on the presence of organic and inorganic pollutants. Environmental Science and Pollution Research 23:18596-18608.

Hoekstra, N.J., T. Bosker, and E.A. Lantinga. 2002. Effects of cattle dung from farms with different feeding strategies on germination and initial root growth of cress (Lepidium sativum L.). Agriculture Ecosystems \& Environment 93:189-196.

Huotari, N., E. Tillman-Sutela, M. Moilanen, and R. Laiho. 2015. Recycling of ash - For the good of the environment? Forest Ecology and Management 348:226-240.

ISO11269-2. 2012. Soil quality -- Determination of the effects of pollutants on soil flora. Part 2: Effects of chemicals on the emergence and growth of higher plants. International Organization for Standardization.

ISO17126. 2005. Soil quality -- Determination of the effects of pollutants on soil flora. Screening test for emergence of lettuce seedlings (Lactuca sativa L.). International Organization for Standardization.

Kataki, S., S. Hazarika, and D.C. Baruah. 2017. Investigation on by-products of bioenergy systems (anaerobic digestion and gasification) as potential crop nutrient using FTIR, XRD, SEM analysis and phyto-toxicity test. Journal of Environmental Management 196:201-216.
Mekki, A., F. Arous, F. Aloui, and S. Sayadi. 2017. Treatment and valorization of agro-wastes as biofertilizers. Waste and Biomass Valorization 8:611-619.

Nafez, A.H., M. Nikaeen, S. Kadkhodaie, M. Hatamzadeh, and S. Moghim. 2015. Sewage sludge composting: quality assessment for agricultural application. Environmental Monitoring and Assessment 187:709.

Nayak, A.K., R. Raja, K.S. Rao, A.K. Shukla, S. Mohanty, M. Shahid, et al. 2015. Effect of fly ash application on soil microbial response and heavy metal accumulation in soil and rice plant. Ecotoxicology and Environmental Safety 114:257262.

ODEPA. 2014. Exportaciones chilenas de celulosa. Diciembre 2014. Oficina de Estudios y Politicas Agrarias, Santiago, Chile. p. 1-8.

Phoungthong, K., H. Zhang, L.M. Shao, and P.J. He. 2016. Variation of the phytotoxicity of municipal solid waste incinerator bottom ash on wheat (Triticum aestivum L.) seed germination with leaching conditions. Chemosphere 146:547-554.

Rios, D., C. Perez, and M. Sandoval. 2012. Phytotoxic effect of paper pulp sludge on Alfisol soil. Journal of Soil Science and Plant Nutrition 12:315-327.

Sadzawka, A., M.A. Carrasco, R. Grez, M. Mora, H. Flores, and A. Neaman. 2006. Métodos de análisis recomendados para los suelos de Chile: Revisión 2006. Instituto de Investigaciones Agropecuarias INIA, Santiago, Chile.

San Martin, V.B., P. Undurraga, C. Quezada, J.E. Celis, and M.A. Sandoval. 2016. Effect of pellets made of waste materials from the paper industry enhanced with seaweed (Ulva lactuca L.) on $\mathrm{N}$ mineralization and lettuce production. Chilean Journal of Agricultural Research 76:363-370.

Sandoval, M., J. Dörner, O. Seguel, J. Cuevas, and D. Rivera. 2012. Métodos de análisis físicos de suelos Universidad de Concepción, Chillán, Chile.

Sandoval, M., M. Zapata, J. Celis, C. Quezada, J. Capulín, and A. Solís. 2013. Efecto de la aplicación de fibra de coco (Cocos nucifera L.) en el almacenamiento y eficiencia del uso del agua en 
un Alfisol, sembrado con ballica (Lolium multiflorum L.) y en la toxicidad en lechuga (Lactuca sativa L.). Ago Sur 41:1-11.

Sharifi, M., M. Cheema, K. McVicar, L. LeBlanc, and S. Fillmore. 2013. Evaluation of liming properties and potassium bioavailability of three Atlantic Canada wood ash sources. Canadian Journal of Plant Science 93:1209-1216.

Sobrero, M.C., and A. Ronco. 2004. Ensayo de toxicidad aguda con semillas de lechuga Lactuca sativa L. In: G. C. (Ed.). Editor Ensayos toxicológicos y métodos de evaluación de calidad de aguas: estandarización, intercalibración, resultados y aplicaciones. Centro Internacional de Investigaciones para el Desarrollo, Ottawa, Canada. p. 71-79.

Stolpe, N., E. Zagal, M. Sandoval, and C. Quezada. 2008. Soil series of the VIII Region of Chile. In: W. R. Base-FAO, editor The International Conference and Field Workshops on Soil Classifica- tion. FAO, Santiago, Ovalle, and Chillán, Chile. November 9-17.

Teaca, C.A., and R. Bodirlau. 2008. Assessment of toxicity of industrial wastes using crop plant assays. Bioresources 3:1130-1145.

Tiquia, S.M. and N.F.Y. Tam. 1998. Elimination of phytotoxicity during co-composting of spent pig-manure sawdust litter and pig sludge. Bioresource Technology 65:43-49.

Undurraga, P., J. Hirzel, J.E. Celis, C. Perez, and M.A. Sandoval. 2017. Pelletized paper mill waste promotes nutrient input and $\mathrm{N}$ mineralization in a degraded Alfisol. Chilean Journal of Agricultural Research 77:390-399.

Unuofin, F.O., M. Siswana, and E.N. Cishe. 2016. Enhancing rock phosphate integration rate for fast bio-transformation of cow-dung waste-paper mixtures to organic fertilizer. Springerplus 5:1986. 